"Financial structure and economic performance in selected African countries: time series evidence"

\begin{tabular}{ll} 
AUTHORS & $\begin{array}{l}\text { Ronald Rateiwa } \\
\text { Meshach Jesse Aziakpono }\end{array}$ \\
\hline ARTICLE INFO & $\begin{array}{l}\text { Ronald Rateiwa and Meshach Jesse Aziakpono (2016). Financial structure and } \\
\text { economic performance in selected African countries: time series evidence. Banks } \\
\text { and Bank Systems, } 11(2), 45-60 . \text { doi:10.21511/bbs.11(2).2016.05 }\end{array}$ \\
\hline DOI & http://dx.doi.org/10.21511/bbs.11(2).2016.05 \\
\hline RELEASED ON & Saturday, 02 July 2016 \\
\hline JOURNAL & "Banks and Bank Systems" \\
\hline FOUNDER & LLC "Consulting Publishing Company "Business Perspectives"
\end{tabular}

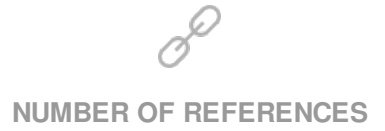

0

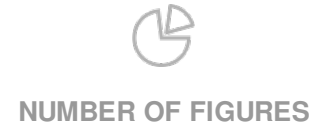

0

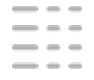

NUMBER OF TABLES

0

(C) The author(s) 2023. This publication is an open access article. 
Ronald Rateiwa (South Africa), Meshach Jesse Aziakpono (South Africa)

\title{
Financial structure and economic performance in selected African countries: time series evidence
}

\begin{abstract}
In this paper, the authors investigate the long-debated question of whether or not a country's financial structure matters for economic performance and, if so, how exactly it matters. The study uses the Johansen cointegration and vector error correction modelling framework within a country-specific setting to examine empirically the existence of a long-run equilibrium relationship between the financial structure of a country and per capita GDP and the causality thereof. The empirical assessment is based on evidence from selected African countries over the period 1971-2013, notably Egypt, Nigeria and South Africa. Firstly, cointegration test results reported in this paper show that there exists a strong relationship between the financial structure of Egypt and South Africa, and per capita GDP in these countries. However, such a relationship is weak in Nigeria, mainly attributable to its low level of financial development and the possibility of the natural resource curse emanating from the oil industry. Secondly, the evidence also strongly suggests that the nature of the relationship between the financial structure of Egypt and South Africa and per capita GDP is positive, albeit based on different measures of financial structure. In Egypt, financial structure is measured by the S-Size ratio, while, in South Africa, it is proxied by the S-Activity ratio. In Nigeria, there is no evidence suggesting that the country's financial structure influences per capita GDP. Lastly, coefficients of the error correction term for all three countries are low, suggesting inefficiencies in the financial system and possible rigidities within the economies.
\end{abstract}

Keywords: financial structure, economic performance, Egypt, Nigeria, South Africa.

JEL Classification: G23, E44, O11, O16.

\section{Introduction}

Financial systems across the globe come in different sizes and shapes. However, given the importance of the financial system - whether by banks or stock markets - to economic growth and poverty reduction (Nguyen, Ali \& Penkar, 2015), the primary policy question confronting governments is: which financial structure is optimal given each country's level of economic growth and circumstances (Beck, Demirguc-Kunt \& Levine, 2001; Lin, Sun \& Jiang, 2009) and Demirgüç-Kunt, Feyen \& Levine, 2011, 2012). Differently put: do countries with market-based financial systems grow faster than those with bankbased financial systems, or is financial structure unrelated to economic performance (Demirgüç-Kunt \& Levine, 2001)? Unfortunately, a cross-reading of the literature revealed that very little scholarship has been committed to understanding whether and, if so, how the financial structure of countries matters for economic growth (Čihák, Demirgüč-Kunt, Feyen \& Levine, 2013).

In addition, results from studies on the subject are not conclusive either in respect of effect or the direction of causality. One of the primary reasons for such variable results is that using different indicators of financial structures produces different results (Čihák, Demirgüč-Kunt Feyen \& Levine, 2013).

(C) Ronald Rateiwa, Meshach Jesse Aziakpono, 2016.

Ronald Rateiwa, University of Stellenbosch Business School, Carl Cronjé Drive, Bellville Park, Cape Town, South Africa and Competition Commission, Pretoria, South Africa.

Meshach Jesse Aziakpono, University of Stellenbosch Business School, Carl Cronje Drive, Bellville Park, Cape Town, South Africa.
The key argument in this regard is that financial markets are multi-dimensional and each measure captures a unique and separate facet of financial systems. Therefore, given the diversity of financial systems and the varied factors that influence them across countries, country-specific studies seem justified to allow for country-specific circumstances to be taken into account. The rationale behind such thinking is to determine if a country's financial structure - specifically the mix of banks and stock markets - influences economic growth within that country.

Recent studies have revealed that financial systems in Africa are not only bank-based, but also shallow, exclusive and tend to lend less to the private sector, compared to other emerging market economies. On the contrary, however, banks in Africa are over-liquid, enjoy huge interest rate spreads and margins, and are, generally, more profitable than their emerging market peers (Beck \& Cull, 2013; Ahokpossi, 2013). These inconsistencies within Africa's financial systems are worrying, given that finance is central to the achievement of the Africa Agenda 2063 and the United Nations' Sustainable Development Goals (SDGs). In addition, poverty remains unacceptably high and per capita GDP is sluggish in Africa. Against this background, we contribute to the financial structureeconomic growth deba te by using time-series evidence from the three largest economies in Africa (Egypt, Nigeria and South Africa) over the period 1975-2013 to investigate the relationship between financial structure and economic performance in each country. Economic performance is measured by per capita Gross Domestic Product (GDP). 
In carrying out this investigation, we use the structure-activity (s-Activity) and the structure-size (sSize) ratios, which ratios capture different aspects of both the banking industry and the stock markets (Beck, Demirguc-Kunt, Levine, \& Maksimovic, 2001; Levine, 2002). The s-Activity ratio measures the activity of the stock market relative to that of banks. It is calculated as the logarithm ratio of total stock market value traded and deposit money bank credit extended to the private sector. Credit to the private sector measures the activity of deposit money banks in channelling savings to investors, while stock market value traded measures liquidity of the stock market. A positive ratio implies a market-based financial system where the stock market dominates the banking sector, while a negative value indicates a bank-based financial system. On the other hand, the s-Size ratio measures the size of the stock market relative to that of banks. It is calculated as the logarithm ratio of total stock market capitalization and deposits of banks. In this case, we use liquid liabilities as being reflective of the size and ability of the banking system to mobilize savings. Positive values of the ratio imply a marketbased financial system (i.e, where the stock market dominates the banking sector), while negative values indicate a bank-based financial system.

In addition, Figure 1 below suggests some positive relationship between financial structure (measured by s-Activity and s-Size ratios) and GDP growth in Egypt, Nigeria and South Africa as evidenced by the co-movement between these ratios and GDP. Although this suggests some correlation between financial structure and per capita GDP in all three countries, the exact nature of this relationship can only be estab- lished by applying more rigorous econometric techniques. This study specifically focuses on Egypt, Nigeria and South Africa because of their significance relative to the size and activity of Africa's economy and its financial system. The three selected countries constitute almost half (49\%) of Africa's total GDP. In addition, South Africa, Egypt and Nigeria account for $51 \%, 13 \%$ and $9 \%$ of the total bank assets of the top 100 banks in Africa. This underscores the importance of understanding if and how financial structure in these countries influences economic performance. In light of the above, our study will provide a new perspective on the financial structure-economic growth debate in an African context in the following ways:

This is the first comparative assessment of how the financial structure of a country influences economic performance in the three largest economies of Africa.

The study will assess the relationship between a country's financial structure and economic performance using comprehensive measures of financial structure based on updated (i.e., 2015) data. To the best of our knowledge, this is the first time-series study on this subject specifically focusing on African countries using pre- and post-global crisis data. The need to cover both the pre- and post-global crisis data was highlighted in study by Nguyen, Islam \& Ali (2013) on equity price indices in Asian countries.

We hope that the results from our study of these countries will stimulate policy discussion in other countries in Africa.

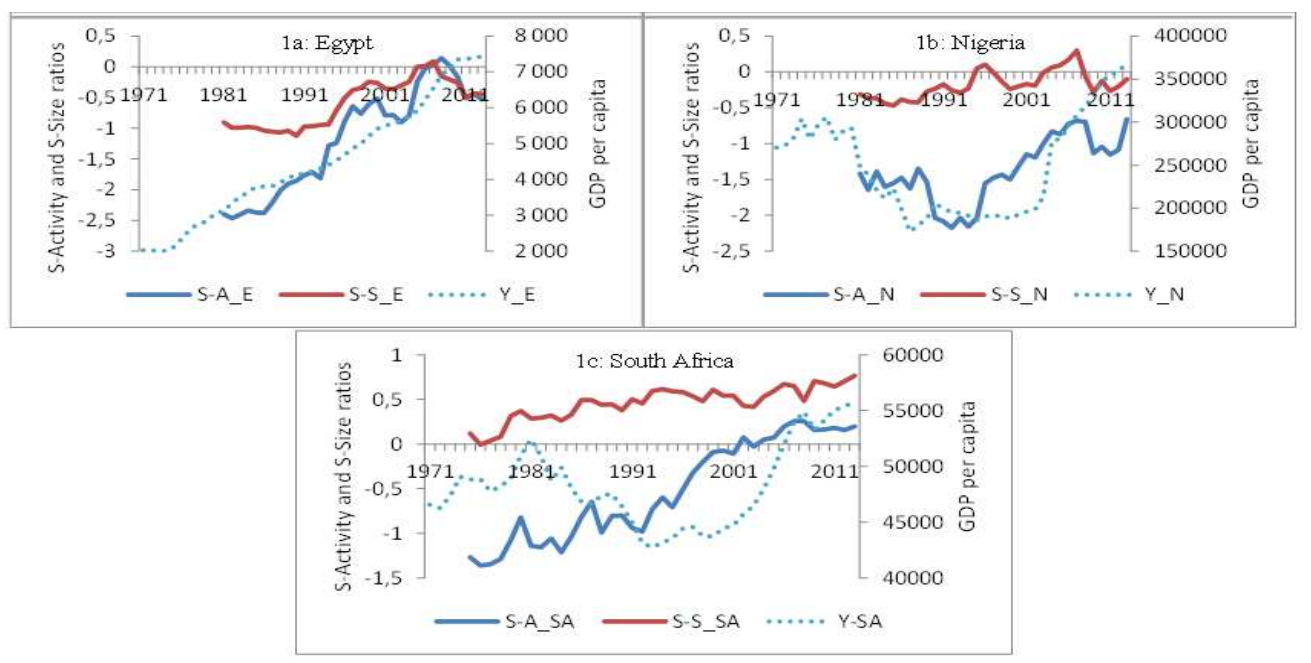

Source: Global Development Finance Database (2013), World Development Indicators (2015), Central Banks of Nigeria, Egypt and South Africa.

Notes: s-Size $=$ Ln [Stock Market capitalisation/Liquid liabilities of deposit money banks]; s-Activity $=$ Ln [Stock market value traded/Deposit money bank credit to the private sector]. S-S_E, S-S_N and S-S_SA is the S-Size for Egypt, Nigeria and South Africa, respectively. S-A_E, S-A_N and S-A_SA is the S-Activity for Egypt, Nigeria and South Africa, respectively. Y-E, Y_N and Y_SA is the GDP per capita for Egypt, Nigeria and South Africa, respectively.

Fig. 1. Co-movement between financial structure and per capita GDP for Egypt, Nigeria and South Africa: 1975-2013 
The remainder of the paper is organized as follows: section 1 provides the theoretical link between financial structure and economic performance; section 2 provides an overview of the financial systems in Africa; section 3 presents the methodology; section 4 presents the empirical results; and final section concludes.

\section{Financial structure and economic performance}

A cross-reading of the literature suggests that financial structure can be defined using various terms such as the mix, composition, organization, balancedness or the relative importance of various financial institutions and the services they offer in each economy at a particular point in time (Stulz, 2000; Cuadro-Sáez \& García-Herrero, 2007; Lin, Sun \& Jiang, 2009; Cull, Demirguc-Kunt \& Lin, 2013). However, as the debate around the finance-growth nexus continued into the new millennium, competing theories have emerged regarding which financial structure is more suitable in promoting economic performance. Specifically, some observers have argued that financial systems dominated by banks (i.e., bank-based financial systems) perform better than those that are dominated by stock markets (i.e., market-based systems). On the other hand, proponents of the market-based financial system argue that stock markets perform better in promoting economic performance (Beck, Demirguc-Kunt, Levine, \& Maksimovic, 2001; Levine, 2002). A third group, assuming the financial services view, argues that neither banks nor stock markets are superior in promoting per capita GDP, but that it is rather the complementary development of both banks and stock markets that is required to support per capita
GDP. Lastly, the law and finance view sees the historical development of law in a specific region as being influential on the effectiveness of financial systems in supporting economic performance of a country (La Porta, Lopez-de-Silanes, Shleifer \& Vishny, 1996; Levine, Law, 1999).

Given the divergent theories presented above, the concomitant question is does the financial structure of a country (whether bank-based or market-based) matter for economic performance? Before we present empirical evidence on this question, we discuss the different measures of financial structure below.

1.1. Measuring financial structure. In order to measure the relationship between financial structure and economic performance, the first step is to find a way to empirically measure financial structure. However, there is no universally accepted definition of financial structure (Levine, 2002), thus, posing an added challenge in measuring it. Čihák, Demirgüč-Kunt, Feyen \& Levine (2013) suggest that financial markets come in different shapes and sizes. Specifically, they argue that there is massive disparity between financial systems around the globe. This implies that focusing on only one aspect, for instance financial system depth or stability, means missing out on other equally important aspects such as access and efficiency.

In this study, we use the s-Activity and s-Size ratios which capture the liquidity and size of both banks and stock markets. Figure 2 below shows the changes in the structure of financial systems in Egypt, Nigeria and South Africa over the period 1975 to 2013.
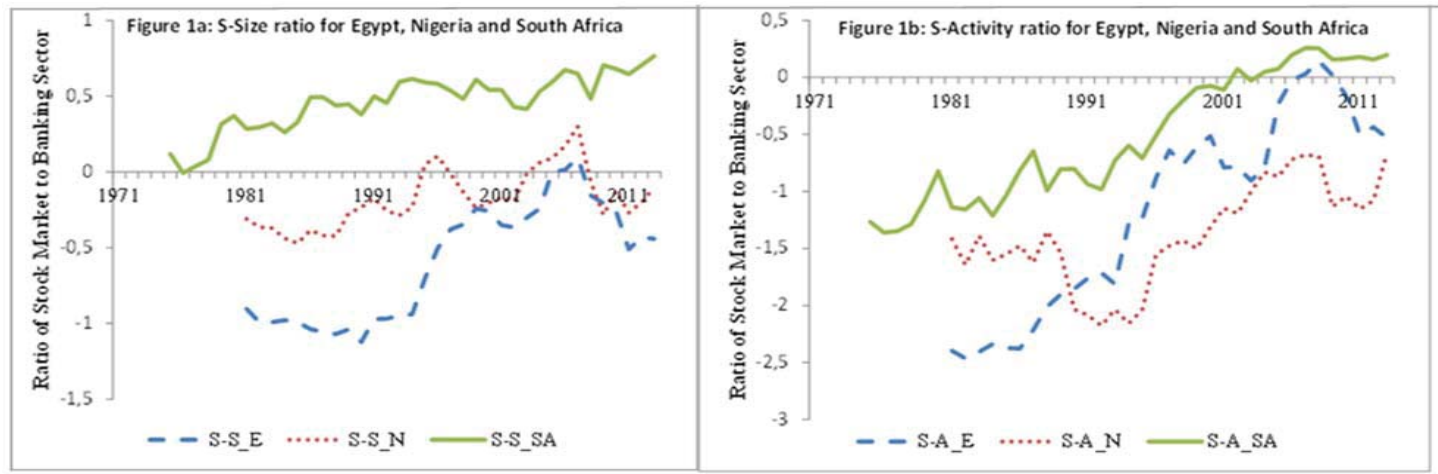

Source: Global Development Finance Database (2013), World Development Indicators (2015), Central Banks of Nigeria, Egypt and South Africa.

Notes: s-Size $=$ Ln [Stock Market capitalisation/Liquid liabilities of deposit money banks]; S-Activity $=$ Ln [Stock market value traded/Deposit money bank credit to the private sector]. S-S_E, S-S_N and S-S_SA is the S-Size for Egypt, Nigeria and South Africa, respectively. S-A_E, S-A_N and S-A_SA is the S-Activity for Egypt, Nigeria and South Africa, respectively.

Fig. 2. S-Size and S-Activity ratios for Egypt, Nigeria and South Africa: 1975-2013

Figure 2a above shows that South Africa has a financial system that is dominated by stock markets, compared to that of Egypt and Nigeria, whose financial systems are dominated by banks. Unlike 
South Africa, the size of Egypt and Nigeria's banking sector is bigger than the size of their stock markets, except over the period 1993-97 and 20032008, when the two were almost equal in size. The S-Activity ratio in Figure $2 b$ shows that although financial systems in all three countries were predominantly bank based over the period under review, the figure shows a significant increase in stock market activity.

\subsection{Apriori expectation between financial struc-} ture and per capita GDP. Based on (Beck, Demirguc-Kunt, Levine, \& Maksimovic, 2001 and Levine, 2002), the relationship between financial structure (measured by the indicators stated above) and economic performance can be expressed as:

$$
Y_{t}=\alpha X_{t}+\beta F D_{t}+\gamma F S_{t}+\varepsilon_{t} 1
$$

Where $Y$ is the real per capita GDP, $X$ is a set of control variables for per capita GDP, $F D 2$ is an indicator of overall financial development, $F S$ is the financial structure ratio and $\varepsilon$ is the error term. The above representation has four possible hypotheses:

Firstly, the market-based view predicts that stock markets grow faster than banks and their influence on economic performance is therefore more significant, implying that $\beta$ and $\gamma$ should be greater than zero. Thus, if the parameter $\beta$ and $\gamma$ are positive and statistically significant, then the financial structure is marketbased. The sign and significance of $\gamma$ is premised on the argument that in a market-based financial system, the S-Size and S-Activity ratios will be greater than 1 (Beck, Demirguc-Kunt, Levine, \& Maksimovic, 2001).

Secondly, the bank-based view predicts that banks grow faster than stock markets and their influence on economic performance is accordingly more significant, implying that $\beta$ should be greater than zero and $\gamma$ should be less than zero. Literature suggests that in a bank-based financial system, the S-Size and SActivity ratios will be positive (Beck, Demirguc-Kunt, \& Levine, 2001).

Lastly, the financial services view predicts that $\beta$ should be greater than zero and $\gamma$ should be equal to zero. Thus, the relationship between financial structure ratio (S-Size and S-Activity) and economic performance is positive but not significant.

In addition to the hypotheses stated above, the literature suggests that the relationship between a country's financial development (which can be proxied by financial structure as in this case) and economic performance is not only unidirectional (i.e. running from financial development to economic performance), but can also be a sequential (Patrick, 1966) or a simulta-

${ }^{2} \mathrm{FD}$ is measured as the product of the S-Size and S-Activity ratios. neous two-way causality (Berthelemy \& Varoudakis, 1996). Patrick (1966) argues that the relationship between financial development and economic performance can either be demand-following or supplyleading. On the other hand, Berthelemy \& Varoudakis (1996) hold that such a relationship can either take the form of a vicious or virtuous cycle.

Therefore, it is the objective of this study is not to only establish the existence of a long-run equilibrium relationship between financial structure and economic performance, but also ascertain the causality thereof.

1.3. Selective review of empirical studies on financial structure and per capita GDP. The empirical debate on whether a bank-based or stock market-based financial system is superior in promoting economic performance remains an ongoing one. Evidence from market-based financial systems (typically the United States, the United Kingdom and Canada) and bankbased financial systems (typically Germany, France and Japan) show that both types of financial systems provide different services to the economy in different ways. Specifically, a study by Allen \& Gale (1995) shows that despite vast differences in the structure of their financial systems, all these countries enjoyed significant improvement in economic performance.

Beck, Demirguc-Kunt, Levine \& Maksimovic (2001) and Levine (2002) are among the early studies based on cross-country evidence to conclude that financial structure (measured by the S-Activity and S-Size ratios) is not significantly associated with economic performance. Furthermore, Beck \& Levine (2002) also used the structure-aggregate ratio (the first principle component of S-Activity and S-Size ratios) to illustrate that financial structure is not significantly associated with 'industrial growth patterns or the efficiency of capital allocation'.

Another study supporting the hypothesis that financial structure does not influence economic performance is Mahonye \& Ojah (2014). The study was based on cross-country evidence from 15 African countries and used the S-Activity ratio as a measure of financial structure. Egypt, Nigeria and South Africa were covered in all the studies mentioned above.

By contrast, a cross-country study by Tadesse (2002) concluded that financial structure matters for a country's economic performance. Specifically, the study used a conglomerate measure of financial structure (the principle component of S-Activity, S-Size and S-Efficiency ${ }^{3}$ ), concluding that in countries with higher levels of financial development, marketbased financial systems outperform bank-based financial systems in stimulating economic perfor-

${ }^{3} \mathrm{~S}$-Efficiency was measured as total stock market value traded divided by the ratio of a bank's overheads costs to total assets. 
mance. Furthermore, the study found that in countries dominated by small firms, bank-based financial systems stimulate ecconomic growth faster than market-based financial systems which are more efficient in promoting economic performance in countries dominated by larger firms.

In addition, using a financial structure ratio measured as credit to the private sector divided by stock market value traded, Demirgüç-Kunt, Feyen, \& Levine (2011) concluded that as the economy grows, its sensitivity to the development of a market-based financial system increases while sensitivity to the development of a bank-based financial system decreases. Thus, they conclude that different financial institutions offer different services to the economy and, as the economy grows, it requires different mixtures of these institutions.

Another study arguing that financial structure matters for economic performance is that of (Yeh, Huang, \& Lin, 2013) Using S-Activity, S-Size and S-Efficiency ratios, they demonstrate that financial structure is positively and significantly cointegrated with economic performance and its volatility. It is also important to note that Egypt, Nigeria and South Africa were also part of the sample countries included in all these studies.

In order to improve on the weaknesses of crosscountry approaches used in the studies reviewed above, which ignore heterogeneity in financial structure and economic dynamics, Bolbola, Fatheldina, \& Omranb (2005); Arestis, Luintelc, \& Luintel (2010); Ahmed \& Wahid (2011); Solo (2013) and Oima \& Ojwang (2013) apply time-series techniques to investigate the relationship between financial structure and economic performance in certain African countries. We explore each of the studies in detail below, specifically in respect of the three countries being investigated in this study.

Bolbola, Fatheldina, \& Omranb (2005) focuses on Egypt to conclude, based on linear regression, that financial structure is positively associated with total factor productivity (TFP). Financial structure is measured by S-Size and S-Activity ${ }^{4}$ over the period 1980-2002. However, a more recent study (Solo, 2013) used the VECM framework to conclude that financial structure (S-Size, measured over the period 1990-2008) is negatively associated with growth in Egypt. Although both sets of results suggest that the financial structure of a country matters for economic performance, results indicating the

\footnotetext{
${ }^{4} \mathrm{~S}$-Size was measured as market capitalisation/commercial bank assets, while S-Activity was measured as stock market value traded/domestic credit to the private sector.
}

opposite imply that the debate on whether banks or stock markets are more effective in promoting economic performance in Egypt remains ongoing.

The second body of literature focuses on Nigeria (Ahmed \& Wahid, 2011; Solo, 2013 and Oima \& Ojwang, 2013), with both these studies concluding that the relationship between financial structure and per capita GDP is positive and significant. Ahmed \& Wahid (2011) employed the VECM framework wherein finacial structure was measured as the first principle component of S-Activity and S-Size over the period 1987-2007. Oima \& Ojwang (2013) applied the ordinary least squares methodology (OLS) to assess the relationship between financial structure (S-Size) and per capita GDP over the period 1976-2008.

The next group of time series studies focused on South Africa (Arestis, Luintelc, \& Luintel, 2010; Ahmed \& Wahid, 2011 and Solo, 2013). These studies produced conflicting results regarding the relationship between financial structure and per capita GDP. Arestis, Luintelc, \& Luintel, 2010; and Solo, 2013) used the S-Size as a measure of financial structure and found that the relationship between financial structure and economic performance is negative. Arestis, Luintelc, \& Luintel (2010) employed the VAR framework and covered the period 1969-1999, while Solo (2013) employe the VECM framework over the period 1990 to 2008. On the other hand, Ahmed \& Wahid (2011) employed the VECM framework wherein finacial structure was measured as the first principle component of S-Activity and S-Size over the period 1987-2007 to conclude that the relationship between financial structure and economic performance is positive.

In addition to the stark contrast in the results of studies reviewed above, our literature review shows that none of the time-series studies investigated the independent influence of the comparative liquidity of financial systems (S-Activity) on economic performance in Egypt, Nigeria and South Africa. The S-Activity ratio, which the literature suggests is a good predictor of economic performance, was either completely left out of the analysis or only used as part of a principal component. This results in the relationship between financial structure and economic performance either being over- or underestimated. Secondly, the studies for the three countries covered different periods and applied different econometric methodologies; which makes comparison of the results difficult. Lastly, all the previous studies covered periods up to 2008, suggesting that no study has covered the period after the global financial crisis. This study aims to contribute to the 
existing body of literature by investigating the independent effect of S-Activity and S-Size on economic performance in Egypt, Nigeria and South Africa, covering the period before and after the global financial crisis. Applying the same methodology for all the three countries makes the results comparable. We hope that the results from this study will contribute to resolving the debate on whether financial structure matters for economic performance in Africa. In addition, recommendations from this study should also assist policymakers in coming up with appropriate financial sector policies that promote economic performance in Africa, especially at a time when countries work towards the Africa Agenda 2063 and the SDGs.

\section{Methodology}

In this paper we follow the traditional approach to investigate the finance-growth nexus, according to which we regress per capita GDP $(Y)$ on financial development (FD) together with other control variables, that is $Y=f(\mathrm{FD}$, control variable(s)) (Levine, 1997). Per capita GDP is proxied by log of per capita real GDP. Our decision to use log of per capita real GDP is consistent most time series studies, while cross-country studies use the growth rate of per capital GDP (Luintel \& Khan, 1999; Aziakpono, 2008; Arestis, Luintelc \& Luintel, 2010 and Yeh, Huang \& Lin, 2013). As indicated above, in the equation, FS will be proxied by financial structure ratios (i.e. S-Activity and S-Size).

To empirically examine this relationship, this study uses the Johansen cointegration and vector error correction model within a country-specific setting. This approach provides a framework for testing the existence of a long-run equilibrium relationship between $Y$ and $F D$, and the causality thereof.
Based on Aziakpono (2008) and Arestis, Luintelc \& Luintel (2010), the multivariate vector error correction model with $k$ lags can be expressed as follows:

$$
\Delta X_{t}=\prod X_{t-1}+\sum_{t=1}^{\mathrm{k}} \mathrm{r} \Delta_{\Delta} X_{t-1}+\varepsilon_{k t} .
$$

Where $X_{t}=f(\mathrm{Y}, \mathrm{FD}$, control variable $)$ is a $3 \mathrm{x} 1$ vector. The variables are integrated of order 1 , that is, $I$ (1). Moreover, $\Delta X_{t}$ is $I(0)$, $\Gamma \mathrm{i}$ represents $3 \times 3$ shortrun coefficient matrices, and $\varepsilon \mathrm{k} t$ is the error term and is normally and independently distributed.

The full rank of $\prod i$ matrix is $\mathrm{r}$. In a trivariate model (where $n=3$ ), if $r=3$, then the variables $X_{t}$ are $I(0)$. However, if the rank of the $\prod$ matrix is zero, then there are no cointegrating relationships between the variables. The $\prod$ matrix can also have a reduced rank in the order of $r \leq(n-1)$. Thus, in a trivariate model, two reduced ranks are possible: $r=1$ (one cointegrating vector) and $r=2$ (two cointegrating vectors).

This paper uses a trivariate model following the approach used by Luintel \& Khan (1999); Aziakpono (2008) and Arestis, Luintelc, \& Luintel (2010). In the trivariate model one control variable is added at a time. $\mathrm{Y}$ and $\mathrm{FD}$ remain constant in the model since they are the variables of interest. Adding one variable at a time helps to address the possible misspecification problem inherent in a bivariate model, which may result in erroneous causal inferences (Luintel \& Khan, 1999). Furthermore, it helps to test the robustness of the long-run relationship between Y and FD. Specifically, a trivariate model enables us to test if the long-run relationship is affected by the control variable used.

In Table 1 below, we briefly discuss the apriori expectation of the control variables based on theory and empirical literature. All variables were measured as a percentage of nominal GDP, except inflation and interest rates.

Table 1. Description of control variables

\begin{tabular}{|c|c|}
\hline Concept being measured & Variable and description \\
\hline Macroeconomic stability & $\begin{array}{l}\text { Macroeconomic instability distorts financial contracting (Demirgüç-Kunt and Levine, 2001). Empirical evidence suggests that inflation } \\
\text { is highly correlated with under-development of both banks and stock markets. In the same breath, an unstable macroeconomic } \\
\text { environment adversely affects the development of financial institutions (Levine, 2004). }\end{array}$ \\
\hline Trade openness & $\begin{array}{l}\text { Exports, imports and openness (exports plus imports as a percentage of GDP). The need to develop appropriate instruments to } \\
\text { finance international trade and portfolio investments may facilitate financial development (Rajan \& Zingales, 2000). Thus, trade } \\
\text { openness should be positively correlated with the development of both banks and stock markets. }\end{array}$ \\
\hline Infrastructure & $\begin{array}{l}\text { The availability of infrastructure is expected to facilitate economic and financial transaction, such as banking and stock market } \\
\text { trading. Therefore, the lack of it may affect the development of both banks and stock markets. Conversely, the lack of infrastructure } \\
\text { may be indicative of potential for investment which may stimulate the development of financial instruments to finance its develop- } \\
\text { ment. This suggests that the effect of infrastructure on financial structure and development can be positive or negative. }\end{array}$ \\
\hline Government fiscal policy & $\begin{array}{l}\text { Growth in government expenditure could affect financial structure if it crowds out the private sector, which may cause financial } \\
\text { under-development. However, according to the World Bank report titled, Rethinking the Role of State in Finance (2013), government } \\
\text { intervention through credit guarantee schemes can enhance stability of the financial markets, thus promoting development of banks } \\
\text { and stock markets. }\end{array}$ \\
\hline Natural resources & $\begin{array}{l}\text { While theory suggests that natural resources attracts foreign direct investment, which should in turn promote economic and financial } \\
\text { development, recent literature suggests that natural resources may inhibit per capita GDP (Ploeg \& Poelhekke, 2007). This is } \\
\text { referred to as the 'natural resource curse'. On the other hand, availability of natural resources suggests potential for industrial growth } \\
\text { and exports, both of which are expected to have a positive effect on per capita GDP (Sala-i-Martin \& Subramanian, 2003). }\end{array}$ \\
\hline
\end{tabular}


Table 1 (cont.). Description of control variables

\begin{tabular}{|l|l|}
\hline Concept being measured & \multicolumn{1}{c|}{ Variable and description } \\
\hline Interest rates & $\begin{array}{l}\text { Literature suggests that interest rates influence both the supply and demand of financial services. High deposit rates are expected to } \\
\text { attract savings which are then invested into the economy (Nguyen, Ali, \& Penkar, 2015). On the other hand, high lending rates } \\
\text { discourage borrowing for investment in productive assets Beck, Fuchs \& Uy (2009) and Beck \& Cull (2013). Thus a wide interest } \\
\text { rate spread is likely to retard the development of banks, thus reducing per capita GDP. }\end{array}$ \\
\hline
\end{tabular}

Source: Compiled by author.

2.1. Data and sources. Data used in estimating the model is annual and covers the period 1971-2013, but was not available for the entire period for some of the variables. The period of study was chosen solely due to data limitations, which problem is characteristic of African countries. GDP data for the three countries was obtained from the World Development Indicators (WDIs) and the United Nations Statistics (UN Stats). Banking sector and stock market development data was obtained from the International Financial Statistics (IFS), the WDIs and the World Federation of Exchanges (WFE). Data on the control variables was obtained from the IFS and the WDIs. Gaps in the data were filled in by data obtained from the central banks and stock market markets in Egypt, Nigeria and South Africa (See Table 2 for the full description of variables and period of coverage).

2.2. Estimation results. This section presents and discusses the results. The results are presented in four sections: (1) results from the unit root test; (2) cointegration results; (3) weak exogeneity and causality test results; and (4) the long-run relationship between financial structure and economic performance.

2.3. Unit root test results. In order to test the stationarity of the variables we use two test methods, namely the Augmented Dickey Fuller and the breakpoint unit root test as a confirmatory test. For Egypt and Nigeria, the unit root and stationarity test results show that most of the variables are first difference stationary, that is, I (1) series. The only exception was oil rents and interest rate spread that were stationary at level for both countries. Similarly, for South Africa, the unit root and stationarity test results also show that most of the variables were I (1) series. The only variables that were level stationary were lending and deposit rates, spread, exports, imports and net taxes.

The next step is to carry out a cointegration test to determine whether or not a long-run relationship exists among the variables.

2.4. Cointegration results. We use the Johansen cointegration technique to test for cointegration. Table 3 below presents the cointegration test results. In the table "K" indicates the vector autoregression (VAR) order which produces a white noise residual, and 'A' indicates the deterministic trend assumption for each particular model. These models invariably produced meaningful results, that is, they satisfied serial correlation, heteroscedasticity and adjusted R2 specifications (30\%). The detailed results are presented in Table 3 and Table 4 (see Appendix).

At least 44 models were estimated for each country based on the financial structure ratios (i.e. the SActivity and S-Size ratios).

\section{Egypt}

For Egypt, the trace and the max eigenvalue tests show the existence of a long-run equilibrium relationship between financial structure and per capita GDP. Such a relationship was shown by cointegration in at least 19 models. Of these 19 models, 8 show cointegration between S-Activity and economic performance, while the remaining 11 show cointegration between S-Size and economic performance. This suggests a strong long-run relationship between financial structure and economic performance, implying that the degree to which bank or stock markets dominate the financial system matters for economic performance in Egypt.

\section{Nigeria}

In Nigeria, the trace and the max eigenvalue tests show that although financial structure matters for economic performance, evidence to that effect is weak. Specifically, only 8 models show the existence of a long-run relationship between economic performance and financial structure (both S-Activity and S-Size). Of the 8 models reported in this regard, only 1 shows a relationship between S-Activity and economic performance, while the remaining 7 represent the relationship between S-Size and economic performance. The weak long-run relationship between financial structure and economic performance in Nigeria is not surprising given the low level of development of financial systems in the country. In addition, given the fact that one of the sectors consuming the bulk of deposit money bank private sector credit is the oil industry, which has a limited feedback effect on the economy, the relationship between financial structure (notably the SActivity ratio) and economic performance is likely to be weak. This could be as a result of the natural resource curse (Sala-i-Martin \& Subramanian, 2003). The natural resource curse occurs when the availability of natural resources fails to promote economic performance but rather inhibit it. 


\section{South Africa}

The trace and the max eigenvalue tests show that financial structure is cointegrated with economic performance in 12 models in South Africa. Specifically, 7 models show that the S-Activity ratio has a longrun relationship with economic performance, while the other 5 represent the relationship between S-Size ratio and economic performance. The evidence suggests that in South Africa, unlike Egypt and Nigeria, the relative activity of both banks and the stock market is more strongly cointegrated with economic performance than their relative sizes. This is not surprising given that the activity of both the stock market and credit to the private sector in South Africa is the highest among African countries and comparable to other developed countries.

Overall, evidence shows that there exists a strong relationship between financial structure and economic performance in Egypt and South Africa, while such a relationship is weak for Nigeria. In addition, the evidence also shows that in Egypt and Nigeria, the relative size of these countries' stock markets to that of banks matters more economic performance than their relative activity.

The existence of cointegration implies that causality must at least run from one of the variables to the other. However, the exact nature of the relationship between financial structure and economic performance in the three countries will be established in the following sections, where the direction of causality and statistical significance of the results will be tested. The next section presents the weak exogeneity test results to determine the nature (direction) of the causal link between economic performance and the financial structure ratios used in this study.

2.4.1. Causality between financial structure and economic performance. Given the conflicting views in respect of the causal link between financial structure and economic performance, what prevails within each particular setting becomes an empirical issue. In this paper we use the weak exogeneity approach to test the direction of causality between financial structure and economic performance. The detailed weak exogeneity results and the direction of causality thereof are reported in Tables 3 and 4 above. The tables report the Chi-square statistic and the probability value of the test. Specifically, it presents three null hypotheses: (1) the two-way causality between economic performance and financial structure; (2) causality running from economic performance to financial structure; and (3) causality running from financial structure to economic performance. A 'Yes' indicates that the null hypothesis cannot be rejected while a 'No' indicates that the null hypothesis is rejected. The results are then discussed separately for each country.

\section{Egypt}

Results presented in Table 3 show that when using the S-Activity ratio, causality predominantly runs from per capita GDP to financial structure as reported in 6 of the models, compared to only 2 in the opposite direction (i.e. from financial structure to per capita GDP). However, when the S-Size ratio is used causality predominantly runs from financial structure to per capita GDP as shown by 9 models, compared to only 3 in the opposite direction. This shows that the evidence strongly suggests that regardless of the measure used, causality between financial structure and economic performance in Egypt predominantly runs from financial structure to economic performance. Thus, overall the evidence suggests a supply-leading relationship, wherein banks and stock markets develop financial instruments in advance of their demand by the real economy.

\section{Nigeria}

With regard to Nigeria, evidence of causality between financial structure and economic performance is not only weak, but also mixed. The evidence shows that when using the S-Activity ratio, the only model reported in this regard shows causality running from financial structure to per capita GDP. On the other hand, models based on the S-Size ratio show that causality runs predominantly from per capita GDP to financial structure. This suggests that the long-run relationship between financial structure and economic performance is likely to be as a result of economic performance influencing the financial structure, and not the other way round.

\section{South Africa}

The weak exogeneity test results summarised in Table 3 show that the causality between financial structure and economic performance in South Africapredo minantly runs from financial structure to per capita GDP when using the S-Activity ratio. A total of 6 models were reported in this regard, with 3 showing causality running in the opposite direction. This suggests that the activity of the stock markets and banks is important in influencing economic performance in South Africa. However, when we consider the S-Size ratio, 5 models show causality running from per capita GDP to financial structure, while only 1 model shows causality running in the opposite direction. Overall, this suggests that the liquidity of the stock market and the activity of banks are more likely to influence economic performance in South Africa than their relative sizes.

The next section presents the economic and statistical significance of the relationship between financial structure and economic performance. The objective of this section is to show the nature of the long-run relationship between financial structure and economic performance. 
2.4.2. Long-run relationship between financial structure and economic performance. The coefficients of the long-run relationship between financial structure and per capita GDP are presented in Tables 5 and 6 below, which tables also reports the coefficients of error correction term. The coefficient of the error correction term describes the speed of adjustment by the dependent variable back to equilibrium, after a shock in the short run. The third column in the table presents the long-run coefficient and its corresponding t-statistic, while the fourth column reports the coefficients of the error correction term.

Table 2. Long run parameters: S-Activity and per capita GDP

\begin{tabular}{|c|c|c|c|c|c|c|c|}
\hline & Control variable & Obs & $\mathrm{K}$ & $A$ & $Y(Y \rightarrow F D)$ & $F D(Y \leftarrow F D)$ & ECM Term \\
\hline \multirow{8}{*}{ Egypt } & Agric & 29 & 3 & 4 & $-23.97[-4.54]^{\star \star \star}$ & & $-0.63[-4.43]$ \\
\hline & ElecPecapita & 28 & 3 & 2 & $-28.28[-3.86]^{\star \star *}$ & & $-0.55[-4.54]$ \\
\hline & GasRents & 29 & 3 & 4 & $-50.98[-4.84]^{\star * *}$ & & $-0.34[-4.84]$ \\
\hline & GrtCons & 28 & 4 & 3 & $6.02[15.19]^{* * *}$ & & $-0.39[-2.16]$ \\
\hline & LendingR & 29 & 3 & 4 & $-26.94[-3.91]^{\star \star *}$ & & $-0.55[-4.84]$ \\
\hline & NetTaxes & 29 & 3 & 4 & $-8.06[-1.81]^{\star}$ & & $-0.81[-4.15]$ \\
\hline & PDensity & 29 & 3 & 3 & $-41.26[-6.53]^{\star \star \star}$ & & $-0.48[-4.65]$ \\
\hline & Pop & 29 & 3 & 3 & $-55.26[-6.90]^{\star \star *}$ & & $-0.50[-6.65]$ \\
\hline Nigeria & Imports & 28 & 4 & 2 & & $0.46[4.55]^{\star \star \star}$ & $-0.09[-2.27]$ \\
\hline \multirow{7}{*}{ South Africa } & ElecPecapita & 32 & 4 & 3 & & $0.21[3.95]^{\star \star *}$ & $-0.13[-2.68]$ \\
\hline & ER_av & 35 & 3 & 2 & & $0.30[5.48]^{\star \star \star}$ & $-0.11[-2.43]$ \\
\hline & ER_end & 35 & 3 & 2 & & $0.31[6.62]^{\star \star \star}$ & $-0.10[-2.06]$ \\
\hline & GCF & 34 & 4 & 4 & $-11.41[-4.16]^{\star * *}$ & & $-0.83[-4.82]$ \\
\hline & LendingR & 35 & 3 & 4 & & $0.20[3.55]^{\star \star \star}$ & $-0.12[-3.35]$ \\
\hline & Tel100 & 35 & 3 & 3 & & $0.14[8.67]^{\star \star \star}$ & $-0.32[-4.24]$ \\
\hline & UrbanPop & 34 & 4 & 4 & & $0.10[5.39]^{\star * \star}$ & $-0.75[-4.19]$ \\
\hline
\end{tabular}

Source: Compiled by author.

Table 3. Long run parameters: S-Size and per capita GDP

\begin{tabular}{|c|c|c|c|c|c|c|c|}
\hline \multirow{13}{*}{ Egypt } & Control variable & Obs & K & A & $Y(Y \rightarrow F D)$ & $F D\left(Y_{\leftarrow F D)}\right.$ & ECM Term \\
\hline & ElecPecapita & 27 & 3 & 4 & $-34.41[-4.16]^{\star \star \star}$ & & $-0.23[-3.30]$ \\
\hline & Exports & 0 & 0 & 0 & & $0.26[7.48]^{\star \star \star}$ & $-0.07[-3.27]$ \\
\hline & GCF & 29 & 3 & 4 & $-39.29[-3.56]^{* * *}$ & & $-0.21[-4.34]$ \\
\hline & Imports & 29 & 3 & 3 & & $0.33[10.40]^{\star \star \star}$ & $-0.07[-2.65]$ \\
\hline & Industr & 29 & 3 & 2 & & $0.13[2.91]^{\star \star *}$ & $-0.06[-2.39]$ \\
\hline & NetTaxes & 28 & 4 & 2 & & $0.41[5.65]^{\star \star \star}$ & $-0.06[-2.94]$ \\
\hline & OPP & 29 & 3 & 3 & & $0.29[10.19]^{\star \star \star}$ & $-0.08[-2.59]$ \\
\hline & PDensity & 29 & 3 & 3 & & $-0.01[-0.49]$ & $-0.47[-3.06]$ \\
\hline & Pop & 29 & 3 & 3 & & $-0.01[-0.49]$ & $-0.47[-3.06]$ \\
\hline & Spread & 29 & 3 & 2 & & $0.29[10.26]^{\star \star \star}$ & $-0.08[-3.82]$ \\
\hline & Tel & 30 & 2 & 2 & & $0.17[4.63]^{\star \star \star}$ & $-0.14[-6.60]$ \\
\hline & Tel100 & 30 & 2 & 2 & & $0.18[4.51]^{\star \star \star}$ & $-0.14[-6.56]$ \\
\hline \multirow{7}{*}{ Nigeria } & Agric & 28 & 4 & 4 & $-0.79[-2.38]^{\star \star}$ & & $-0.90[-4.09]$ \\
\hline & $\mathrm{CPI}$ & 29 & 3 & 3 & $-0.27[-0.61]$ & & $-0.60[-3.10]$ \\
\hline & Elec & 26 & 4 & 3 & & $0.32[1.03]$ & $-0.15[-2.77]$ \\
\hline & Exports & 27 & 5 & 4 & & $-0.12[-0.84]$ & $-0.26[-2.17]$ \\
\hline & Imports & 28 & 4 & 4 & $-1.52[-2.07]^{\star \star}$ & & $-0.78[-4.64]$ \\
\hline & Industr & 28 & 4 & 4 & $-0.94[-1.91]^{\star \star}$ & & $-0.88[-4.63]$ \\
\hline & NetTaxes & 29 & 3 & 2 & $-1.60[-4.06]^{\star \star \star}$ & & $-0.75[-2.94]$ \\
\hline \multirow{5}{*}{$\begin{array}{l}\text { South } \\
\text { Africa }\end{array}$} & ER_av & 35 & 3 & 4 & $-1.32[-1.82]^{*}$ & & $-0.73[-3.61]$ \\
\hline & GutCons & 36 & 2 & 4 & $0.97[1.35]$ & & $-0.53[-3.69]$ \\
\hline & Imports & 36 & 2 & 4 & $1.60[2.69]^{\star \star *}$ & & $-0.85[-5.66]$ \\
\hline & OPP & 36 & 2 & 4 & $2.35[3.54]^{\star \star \star}$ & & $-0.49[-3.22]$ \\
\hline & UrbanPop & 36 & 2 & 4 & $-5.35[-4.54]^{\star \star \star}$ & & $-0.78[-4.49]$ \\
\hline
\end{tabular}

Source: Compiled by author. 


\section{Egypt}

The results presented in Tables 5 and 6 show that the relationship between financial structure and economic performance runs from per capita GDP to financial structure and is negative. Of the 6 models, 5 show a negative relationship between the two variables at a $1 \%$ significance level, while the remaining one shows that such relationship is significant at the 5\% level. This evidence suggests that the relationship between financial structure and economic performance is in line with the bank-based argument indicated above, save for the fact that in this case, it is economic performance that is promoting the development and activity of banks more than stock markets.

However, when we consider the results based on the S-Size ratio, the relationship runs from financial structure to per capita GDP and is positive. All 8 models where the relationship between financial structure and economic performance is positive are significant at $1 \%$. A positive relationship in this case supports the market-based argument, wherein the development of more stock markets will lead to higher economic performance than when deposit money banks accumulate more deposits.

Overall, the weight of the evidence suggests that the relationship between financial structure and economic performance in Egypt is positive. The average coefficient of the S-Size ratio on economic performance for all the positive and significant models is 0.25 . Thus a 1 unit increase in the size of stock markets relative to banks will result in a $25 \%$ change in economic performance. The coefficient of the error correction term averages around 9\%. This suggests that disequilibrium in the economy will take approximately more than ten years to be corrected.

Based on the above, the evidence presented above suggests that while there is potential for a marketbased financial structure to significantly influence economic performance in Egypt, the low coefficient of the error correction term implies rigidities within the economy which may delay restoration of the economy to the equilibrium growth path. Therefore, given the low activity of stock markets and the fact that limited credit is extended to the private sector, financial sector policies in Egypt should focus more on improving liquidity of the stock market and the quantity of credit being channelled to the private sector.

\section{Nigeria}

As indicated above, the relationship between financial structure and economic performance in Nigeria is weak. When using the S-Activity ratio, only one model was reported, which shows a positive and significant relationship. The weak influence of the financial structure on economic performance in Nigeria may be as a result of low levels of credit being extended to the private sector or the illiquidity of its stock markets. Therefore, in order for banks and the stock market to develop to the point that they start positively influencing economic performance, there is a need for financial sector policies in Nigeria to encourage more lending by deposit money banks and share trading on the stock markets, until such a point that it starts to positively influence economic performance.

However, when the S-Size ratio is used, the relationship between financial structure and economic performance is predominantly negative and runs from per capita GDP to financial structure. This suggests that in Nigeria, growth of the economy promotes the development of banks more than stock markets, which finding supports the bank-based argument.

\section{South Africa}

In South Africa, 6 models were reported based on the S-Activity ratio, which models show a positive and significant relationship between financial structure and economic performance. As indicated above, a positive and significant relationship between financial structure and economic performance supports the market-based argument, in terms of which the marginal benefit arising from the development of stock markets is greater than that of banks. In this case, the results suggest that an increase in the liquidity of the stock market compared to increasing credit to the private sector will spur greater economic performance.

On the other hand, when using the S-Size ratio, evidence on the relationship between financial structure and economic performance shows causality running from per capita GDP to financial structure and is mixed. Of the 5 models reported based on the S-Size ratio, 3 show a positive relationship while the remaining 2 show that such a relationship is negative.

On the basis of the above, the weight of the evidence suggests that financial structure based on the SActivity ratio positively influences economic performance in South Africa and significantly so. The coefficient of financial structure on per capita GDP averages around 0.21 . This implies that a 1 unit increase in the liquidity of the stock market relative to the amount of credit being extended to the private sector is expected to increase per capita GDP by $21 \%$. Therefore, in order to stimulate economic performance, financial authorities in South Africa should focus more on policy interventions targeted at improving the amount of trading of the Johannesburg Stock Exchange (JSE) rather than trying to increase the amount of credit extended to the private sector by banks.

The coefficient of the error correction term for South 
Africa is more than $25 \%$ on average, based on the models showing a positive and significant relationship between financial structure and economic performance. This implies that in the case of a disturbance to the equilibrium growth path of the economy, it is likely to take approximately four years for such disequilibrium to be corrected.

\section{Summary of results and conclusion}

This paper investigated the long-debated question of whether or not the financial structure of a country matters for economic performance using selected African countries over the period 1975-2013. The following key findings emerge from this paper: Firstly, cointegration test results reported in this paper show that there exists a strong relationship between financial structure and economic performance in Egypt and South Africa. However, such a relationship is weak in Nigeria, most notably as a result of the low level of financial development in this country and the possibility of the natural resource curse emanating from the oil industry.

Secondly, overall the evidence in respect of the nature of the long-run relationship strongly indicates that financial structure is positively related to economic performance in Egypt and South Africa, albeit based on different indicators of financial structure. In Egypt, financial structure as measured by the S-Size ratio, while in South Africa it is proxied by the S-Activity ratio. In Nigeria, there is no evidence suggesting that financial structure influences economic performance. Rather, it is economic performance that influences financial structure.

Lastly, coefficients of the error correction term for all the three countries are low, suggesting inefficiencies in the financial system and rigidities within the economies. This is particularly more pronounced in Egypt and Nigeria. Specifically, in all cases where financial structure positively influenced economic performance, the average coefficient for the error correction term for Egypt and Nigeria is 0.09, while that for South Africa in 0.25 . This suggests that, in Egypt and Nigeria it takes more than 10 to correct any disequilibrium, while it takes around four years to do the same in South Africa.
The policy implications arising from the empirical results discussed above, for each of the countries and other African countries are summarised below:

Egypt: It is suggested that policies be developed and implemented to improve efficiency of the financial system.

Nigeria: Weak evidence of long -run causality between financial structure and economic performance in Nigeria suggests that factors exogenous to the finance-growth nexus may be at play. In this regard, it is recommended that sufficient policies be developed to create an enabling environment which supports the development of the financial sector and growth of the economy. These recommendations are also in light of findings by Ali \& Medhekar (2013) based on a study in Bangladesh, who concluded that there is need to enhance surveillance of the financial sector and promote the development of capital markets for long-term industrial financing.

South Africa: The relevant authorities must deliberately implement policies to stimulate economic performance and also improve efficiency of the financial system. By doing so, this may create real demand for financial instruments, thus further stimulating financial development.

Lastly, with regard to other African and emerging market economies, we recommend that authorities deliberately implement policies and reform pro grammes to stimulate development of financial systems and also improve their efficiency in intermediating funds. This will unlock funds for investment in long-term productive assets.

The limitation of our study is that it did not explore what the optimal financial structure is for each of the countries included in this sample. Therefore, there is need to further explore not only if and how financial structure matters for economic performance, but what is the optimal financial structure for each country that would efficiently enhance economic performance in that particular country. Secondly, once the optimal financial structure has been established, a study must be carried out to establish if and how deviation from that optimal financial structure influences economic performance.

\section{References}

1. Ahmed, A. D. \& Wahid, A.N. (2011). Financial structure and economic growth link in African countries: a panel cointegration analysis, Journal of Economic Studies, 3, pp.331-357.

2. Ahokpossi, C. (2013). Determinants of bank interest margins in sub-Saharan Africa, International Monetary Fund, $\mathrm{WP} / 13 / 34$.

3. Alderman, H. \& Yemtsov, R. (2013). How can safety nets contribute to economic growth, World Bank, Working Paper 6437.

4. Ali, M. M. \& Medhekar, A. (2013). Role of financial intermediaries in creating international financial shock with special reference to Bangladesh: a critical review. Banks and Bank Systems, pp. 8-22. 
5. Allen, F. \& Gale, D. (1995). A welfare comparison of intermediaries and financial markets in Germany and the US, European Economic Review, 39, pp. 179-209.

6. Ang, J. (2008). What are the mechanisms linking financial development and economic growth in Malaysia? Econometric Modelling, 25, pp. 38-53.

7. Arestis, P., Luintelc, A. D. \& Luintel, K. B. (2010). Financial structure and economic growth: evidence from time series analyses, Applied Financial Economics, 20, pp. 479-1492.

8. Arestisa, P., Luintelc, A. D. \& Luintel, K. B. (2010). Financial structure and economic growth: evidence from time series analyses, Applied Financial Economics, 20, pp. 479-1492.

9. Aziakpono, M. (2011). Financial development and economic growth: theory and a survey of evidence, Journal for Studies in Economics and Econometrics, 35 (1).

10. Aziakpono, M. J. (2007). Effects of financial integration on financial development and economic performance of the SACU countries, United Nations Economic Commission for Africa, Africa Economic Conference 2007.

11. Aziakpono, M.J. (2008). The depth of financial integration and its effects on financial development and economic performance of the SACU countries. Bloemfontein: University of Free State.

12. Beck, T. \& Cull, R. (2013). Banking in Africa. Centre for the Study of African Economies, WPS/2013-16.

13. Beck, T. \& Levine, R. (2002). Industry growth and capital allocation: Does having a market- or bank-based system matter? Journal of Financial Economics, 64, pp. 147-180.

14. Beck, T., Demirguc-Kunt, A. \& Levine, R. (2001). Financial structure and economic growth: Perspectives and lessons. In A. Demirguc-Kun \& R. Levine, Financial structure and economic growth (pp. 17-80). London: The MIT Press.

15. Beck, T., Demirguc-Kunt, A., Levine, R. \& Maksimovic, V. (2001). Financial structure and economic growth: Firm, industry and country evidence. In A. Demirguc-Kunt, \& R. Levine (Eds.), Financial Structure and Economic Growth (pp. 189-242). London: The MIT Press.

16. Berthelemy, J.C. \& Varoudakis, A. (1996). Economic growth, convergence clubs, and the role of financial development, Oxford Economic Papers, 48, pp. 300-328.

17. Bolbola, A.A., Fatheldina, A. \& Omranb, M.M. (2005). Financial development, structure, and economic growth: the case of Egypt, 1974-2002. Research in International Business and Finance, 19, pp. 171-194.

18. Brooks, C. (2014). Introductory econometrics of finance (Third ed.). Cambridge: Cambridge University Press.

19. Cheng, X. \& Degryse, H. (2007). The impact of bank and non-bank financial institutions on local economic growth in China. Bank of Finland: Institute for Economies in Transition, Discussion Paper 22.

20. Čihák, M., Demirgüč-Kunt, A., Feyen, E. \& Levine, R. (2013). Financial development in 205 economies, 1960 to 2010. National Bureau of Economic Research, Working Paper 18946.

21. Cuadro-Sáez, L. \& García-Herrero, A. (2007). Finance for growth: Does a balanced financial structure matter? Bank of International Settlements.

22. Cul, R. \& Beck, T. (2013). Banking in Africa. Centre for the Study of African Economies, WPS/2013-16.

23. Cull, R., Demirguc-Kunt, A. \& Lin, J. Y. (2013). Financial structure and economic development: A Reassessment. The World Bank Economic Review, 1-6.

24. Davis, P. \& Hu, Y.-W. (2008). Does funding of pensions stimulate economic growth? Journal of Pension Economics and Finance, 7 (2), pp. 221-249.

25. Demirgüç-Kunt, A., \& Klapper, L. (2012). Financial inclusion in Africa: An overview, World Bank Research Group, WPS6088.

26. Demirgüç-Kunt, A. \& Levine, R. (2001). Bank-based and market-based financial systems: Cross-country comparison. In A. Demirguc-Kunt, \& R. Levine (Eds.), Financial structure and economic Growth (pp. 81-140). London: The MIT Press.

27. Demirgüç-Kunt, A. \& Levine, R. (2008). Finance, financial sector policies and long-run growth. The World Bank, Commission on Growth and Development (WP No. 11).

28. Demirgüç-Kunt A., Feyen E., \& Levine, R. (2011). The evolving importance of banks and securities markets. World Bank Development Research Group, WPS5805.

29. Demirgüç-Kunt, A., Feyen, E. \& Levine, R. (2012). The evolving importance of banks and securities markets. National Bureau of Economic Research, Working Paper 18004.

30. Engle, R.F., \& Granger, C.W. (1987). Co-integration and error correction: representation, estimation, and testing. Econometrica, 55 (2), pp. 251-276.

31. Eschenbach, F. (2004). Finance and growth: a survey of evidence. Tinbergen Institute, 39(2).

32. Geda, A., Ngungu, N. \& Zerfu, D. (2012). Applied Time Series Econometrics: A practica guide to macroeconomic reserachers with a focus on Africa. Nairobi: Univeristy of Nairobi Press.

33. Gertler, M. (1988). Financial structure and aggregate economic activity, Journal of Money, Credit and Banking, 20 (3), pp. 559-588.

34. Haiss, P. \& Sumegi, K. (2008). The relationship between insurance and economic growth in Europe: a theoretical and empirical analysi, Empirica, 35, pp. 405-431.

35. Harris, L. (2004). From financial development to economic growth and vice versa: A review of international experience and policy lessons for Africa, Journal of African Economies, 21 (1), pp. 89-106.

36. Holzmann, R. (1997). Pension reform, financial market development and economic growth: Preliminary evidence from Chile, International Monetary Fund, 44 (2), pp. 149-178. 
37. Kennedy, P. (2003). A Guide to Econometrics (Fifth ed.). Oxford: Blackwell Publishers Ltd.

38. KPMG Africa Limited. (2013). Financial services in Africa report. KPMG Africa Limited.

39. La Porta, R., Lopez-de-Silanes, F., Shleifer, A. \& Vishny, R. W. (1996). Law and finance. National Bureau of Economic Research, NBER Working Paper 5661.

40. Levine, R. (1997). Financial development and economic growth: views and agenda, Journal of Economic Literature, pp. 688-726.

41. Levine, R. (1999). Law, finance and economic growth, Journal of Financial Intermediation, 8, pp. 8-35.

42. Levine, R. (2002). Bank-based or market-based financial systems: Which is better? Journal of Financial Intermediation, 11 , pp. 398-428.

43. Levine, R. (2004). Finance and growth: Theory and evidence. National Bureau of Economic Research, Working Paper 10777.

44. Levine, R. \& Servos, S. (1998). Stock markets, banks, and economic growth, The American Economic Review, 88 (30), pp. 537.

45. Liang, H.-Y. \& Reichert, A. K. (2012). The impact of banks and non-bank financial institutions on economic growth The Service Industries Journal, 35 (5), pp. 699-717.

46. Lin, J.Y., Sun, X. \& Jiang, Y. (2009). Toward a theory of optimal financial structure. The World Bank, WPS5038.

47. Luintel, K.B., \& Khan, M. (1999). A quantitative reassessment of the finance-growth nexus: evidence from a multivariate VAR, Journal of Development Economics, 60, pp. 381-405.

48. Mahonye, N. \& Ojah, K. (2014). Financial structure and economic development in Africal, Economic Research Southern Africa, 482.

49. Meng, C. \& Pfau, W.D. (2010). Role of pension funds in capital market development, National Graduate Institute for Policy Studies, 10 (17).

50. Mishkin, F. (2007). The economics of money, banking and financial markets. Pearson Education.

51. Mo Ibrahim Foundation. (2013). Africa Ahead: The next fifty years.

52. Nassr, I.K. \& Wehinger, G. (2014). Non-bank debt financing for SMEs: The role of securitisation, private placements and bonds, OECD Journal: Financial Market Trends, 2014 (1).

53. Ndugbu, M.O., Ojiegbe, J., Uzowuru, B.L., \& Okere, P.A. (2015). Bank and non-bank financial institutions and the development of the Nigerian economy, International Journal for Innovation Education and Research, 3 (8).

54. Nguyen, C.V., Ali, M.M. \& Penkar, S. (2015). Asymmetric adjustment in the Singaporean consumer loans-interbank overnight rate spread and conditional heterokedasticity, Business and Economic Journal, pp. 1-7.

55. Nguyen, C.V., Islam, A.M. \& Ali, M.M. (2013). Equity price indices and random walk: The case of Malaysia, Philippines and Taiwan, International Review of Business Research Papers, pp. 28-38.

56. Oima, D. \& Ojwang, C. (2013). Market-based and bank-based financial structure on economic growth in some selected Ecowas ccountries, International Journal of Education and Research, 2.

57. Osuala, A. \& Odunze, C.O. (2014). Do non-bank financial institutions' loans and advances influence economic growth? A bounds test investigation, European Journal of Business and Management, 6 (27).

58. Patrick, H.T. (1966). Financial development and economic growth in underdeveloped countries, Economic Development and Cultural Change, 14 (2), pp. 174-189.

59. Rajan, R.G. \& Zingales, L. (2003). The great reversals: the politics of financial development in the twentieth century, Journal of Financial Economics, 5 (50).

60. Sala-i-Martin, X. \& Subramanian, A. (2003). Addressing the natural resource curse: An illustration from Nigeria. NBER Working Paper Series, Working Paper 9804.

61. Solo, P. (2013). Does financial structure affect economic growth? Evidence from African countries, Journal of Contemporary Management.

62. Stulz, R.M. (2000). Does financial structure matter for economic growth? A corporate finance perspective. The World Bank.

63. Sufian, F. \& Majid, M.-Z.A. (2009). Post-crisis productivity change in nonbank financial institutions: Efficiency increase or technological progress? Journal of Transnational Management, 14, pp. 124-154.

64. Tadesse, S. (2002). Financial architecture and economic performance: International evidence, Journal of Financial Intermediation, 11, pp. 429-454.

65. United Nations Economic Commission For Africa. (2015). Illicit financial flows: Report of the high level panel on illicit financial flows in Africa.

66. Vittas, D. (1997). The role of non-bank financial intermediaries in Egypt and other MENA countries. World Bank Development Research Group.

67. World Bank. (2013). Financing for development, Post 2015.

68. World Bank. (2015). http://data.worldbank.org/data-catalog/GDP-ranking-table. Retrieved August 25, 2015

69. World Bank. (2015). Key Terms Explained: http://econ.worldbank.org/wbsite/external/extdec/ extglobalfinreport/0,contentMDK:23268764 pagePK:64168182 piPK:64168060 theSitePK:8816097,00.html. Retrieved November 13, 2015, from http://econ.worldbank.org/WBSITE/EXTERNAL/EXTDEC/EXTGLOBALFINREPORT/ 0,,contentMDK:23268764 pagePK:64168182 piPK:64168060 theSitePK:8816097,00.html

70. Yeh, C.-C., Huang, H.-C. (., \& Lin, P.-C. (2013). Financial structure on growth and volatility. Economic Modelling, 35, pp. 391-400. 


\section{Appendices}

Tables 2. Description of variables

\begin{tabular}{|c|c|c|c|c|}
\hline & & \multicolumn{3}{|c|}{ Country } \\
\hline Variable & Definition & Egypt & Nigeria & South Africa \\
\hline$Y$ & Real GDP per capita & $1971-2013$ & $1971-2013$ & $1971-2013$ \\
\hline Agric & $\begin{array}{l}\text { Agriculture corresponds to ISIC divisions } 1-5 \text { and includes forestry, hunting, and } \\
\text { fishing, as well as cultivation of crops and livestock production. }\end{array}$ & $1971-2013$ & $1981-2013$ & 1971-2013 \\
\hline $\mathrm{CPI}$ & Consumer Price Index (2010 as base year) & $1971-2013$ & $1971-2013$ & $1971-2013$ \\
\hline Deposith & $\begin{array}{l}\text { Deposit interest rate is the rate offered by commercial banks on three-month depo- } \\
\text { sits. }\end{array}$ & $1976-2013$ & $1971-2013$ & $1977-2013$ \\
\hline Elec & $\begin{array}{l}\text { Electric power consumption measures the production of power plants and combined } \\
\text { heat and power plants less transmission, distribution, and transformation losses and } \\
\text { own use by heat and power plants. }\end{array}$ & $1971-2011$ & $1971-2011$ & $1971-2011$ \\
\hline ElecPecapita & Electric power consumption per capita & 1971-2011 & 1971-2011 & 1971-2011 \\
\hline ERav & National Currency per U.S. Dollar, period average & $1971-2013$ & $1971-2013$ & $1971-2013$ \\
\hline ERend & National Currency per U.S. Dollar, end of period & $1971-2013$ & $1971-2013$ & $1971-2013$ \\
\hline Exports & $\begin{array}{l}\text { Exports of goods and services represent the value of all goods and other market } \\
\text { services provided to the rest of the world }\end{array}$ & $1971-2013$ & $1971-2013$ & $1971-2013$ \\
\hline GasRent & $\begin{array}{l}\text { Natural gas rents are the difference between the value of natural gas production at } \\
\text { world prices and total costs of production. }\end{array}$ & $1971-2013$ & $1971-2013$ & $1971-2013$ \\
\hline GCF & $\begin{array}{l}\text { Gross capital formation (formerly gross domestic investment) consists of outlays on } \\
\text { additions to the fixed assets of the economy plus net changes in the level of invento- } \\
\text { ries }\end{array}$ & $1971-2013$ & $1971-2013$ & $1971-2013$ \\
\hline GvtCons & $\begin{array}{l}\text { Government consumption - final consumption expenditure includes all government } \\
\text { current expenditures for purchases of goods and services (including compensation } \\
\text { of employees). }\end{array}$ & $1971-2013$ & $1971-2013$ & $1971-2013$ \\
\hline Imports & $\begin{array}{l}\text { Imports of goods and services represent the value of all goods and other market } \\
\text { services received from the rest of the world. }\end{array}$ & $1971-2013$ & $1971-2013$ & $1971-2013$ \\
\hline Industri & $\begin{array}{l}\text { It comprises value added in mining, manufacturing, construction, electricity, water, } \\
\text { and gas }\end{array}$ & $1971-2013$ & $1981-2013$ & $1971-2013$ \\
\hline LendingR & Lending rate is the rate charged by banks on loans to the private sector. & 1976-2013 & 1971-2013 & 1971-2013 \\
\hline Mrents & $\begin{array}{l}\text { Mineral rents are the difference between the value of production for a stock of } \\
\text { minerals at world prices and their total costs of production. }\end{array}$ & $1971-2013$ & $1971-2013$ & $1971-2013$ \\
\hline NEREExRate & Nominal Effective Exchange Rate & & $1979-2013$ & $1979-2013$ \\
\hline NetTaxes & $\begin{array}{l}\text { Net taxes on products (net indirect taxes) are the sum of product taxes less subsi- } \\
\text { dies. Product taxes are those taxes payable by producers that relate to the produc- } \\
\text { tion, sale, purchase or use of the goods and services. }\end{array}$ & $1971-2013$ & $1981-2013$ & $1971-2013$ \\
\hline OilRent & $\begin{array}{l}\text { Oil rents - the difference between the value of crude oil production at world prices } \\
\text { and total costs of production as a percentage of GDP. }\end{array}$ & $1971-2013$ & $1971-2013$ & $1971-2013$ \\
\hline OPP & $\begin{array}{l}\text { Openness to trade is the total value of exports and imports, expressed as a percen- } \\
\text { tage of GDP }\end{array}$ & $1971-2013$ & $1971-2013$ & $1971-2013$ \\
\hline PDensity & Population density is midyear population divided by land area in square kilometres. & 1971-2013 & 1971-2013 & $1971-2013$ \\
\hline Pop & Number of people in a particular country & $1971-2013$ & $1971-2013$ & $1971-2013$ \\
\hline Spread & It is the difference between the deposit and the lending rates. & $1976-2013$ & $1971-2013$ & $1977-2013$ \\
\hline Tel & $\begin{array}{l}\text { Telephone lines are fixed telephone lines that connect a subscriber's terminal } \\
\text { equipment to the public switched telephone network and that have a port on a } \\
\text { telephone exchange. Integrated services digital network channels and fixed wireless } \\
\text { subscribers are included }\end{array}$ & $1975-2013$ & $1981-2013$ & $1971-2013$ \\
\hline Tel100 & Telephone lines per every 100 people. & $1975-2013$ & $1981-2013$ & $1971-2013$ \\
\hline UrbanPop & $\begin{array}{l}\text { Population in urban agglomerations of more than one million is the country's popula- } \\
\text { tion living in metropolitan areas that in } 2000 \text { had a population of more than one } \\
\text { million people. }\end{array}$ & $1971-2013$ & $1971-2013$ & $1971-2013$ \\
\hline
\end{tabular}

Source: Compiled by author. 
Table 4. Cointegration and weak exogeneity test results for Egypt, Nigeria and South Africa: S-Activity and per capita GDP

\begin{tabular}{|c|c|c|c|c|c|c|c|c|c|c|c|c|c|c|c|}
\hline & & & & & Trace statistic & & & Max eigenvalue & & & Weak Exogeneity Test & & Causality between $\mathrm{Y}$ and FD & & \\
\hline \multirow{9}{*}{ Egypt } & Control variable & Obs & $\mathrm{K}$ & A & $r<0$ & $r<1$ & $r<2$ & $r<0$ & $r<1$ & $r<2$ & $\mathrm{Y}$ & FD & $Y_{\leftrightarrow} \leftrightarrow F D$ & $\mathrm{Y} \rightarrow \mathrm{FD}$ & $\mathrm{Y} \leftarrow \mathrm{FD}$ \\
\hline & Agric & 29 & 3 & 4 & $53.43[0.00]$ & $25.40[0.06]$ & $6.28[0.43]$ & $28.02[0.03]$ & $19.12[0.05]$ & $6.28[0.43]$ & $0.12[0.73]$ & $9.65[0.00]$ & No & Yes & No \\
\hline & ElecPecapita & 28 & 3 & 2 & $57.32[0.00]$ & $25.48[0.06]$ & $10.93[0.09]$ & $31.84[0.01]$ & $14.55[0.22]$ & $10.93[0.09]$ & $1.54[0.21]$ & $13.12[0.00]$ & No & Yes & No \\
\hline & GasRents & 29 & 3 & 4 & $48.46[0.01]$ & $22.52[0.12]$ & $6.46[0.40]$ & $25.94[0.05]$ & $16.06[0.14]$ & $6.46[0.40]$ & $3.14[0.07]$ & $12.66[0.00]$ & No & Yes & No \\
\hline & GutCons & 28 & 4 & 3 & $48.04[0.00]$ & $12.46[0.14]$ & $0.23[0.63]$ & $35.58[0.00]$ & $12.23[0.10]$ & $0.23[0.63]$ & $1.41[0.24]$ & $6.65[0.01]$ & No & Yes & No \\
\hline & LendingR & 29 & 3 & 4 & $48.84[0.01]$ & $22.65[0.12]$ & $7.94[0.26]$ & $26.19[0.04]$ & $14.71[0.21]$ & $7.94[0.26]$ & $1.09[0.30]$ & $13.70[0.00]$ & No & Yes & No \\
\hline & NetTaxes & 29 & 3 & 4 & $46.73[0.02]$ & $19.23[0.27]$ & $5.51[0.52]$ & $27.50[0.03]$ & $13.72[0.27]$ & $5.51[0.52]$ & $4.17[0.04]$ & $0.01[0.93]$ & No & No & Yes \\
\hline & PDensity & 29 & 3 & 3 & $32.71[0.02]$ & $8.76[0.39]$ & $0.81[0.37]$ & $23.95[0.02]$ & $7.95[0.38]$ & $0.81[0.37]$ & $6.61[0.01]$ & $1.05[0.31]$ & No & No & Yes \\
\hline & Pop & 29 & 3 & 3 & $32.71[0.02]$ & $8.76[0.39]$ & $0.81[0.37]$ & $23.95[0.02]$ & $7.95[0.38]$ & $0.81[0.37]$ & $1.45[0.23]$ & $10.36[0.00]$ & No & Yes & No \\
\hline Nigeria & Imports & 28 & 4 & 2 & $42.86[0.01]$ & $12.49[0.41]$ & $5.50[0.23]$ & $30.38[0.00]$ & $6.99[0.67]$ & $5.50[0.23]$ & $3.11[0.08]$ & $2.25[0.13]$ & No & No & Yes \\
\hline \multirow{7}{*}{ South Africa } & ElecPecapita & 32 & 4 & 3 & $46.44[0.00]$ & $14.80[0.06]$ & $0.56[0.45]$ & $31.65[0.00]$ & $14.23[0.05]$ & $0.56[0.45]$ & $3.11[0.08]$ & $3.91[0.05]$ & Yes & Yes & Yes \\
\hline & ER_av & 35 & 3 & 2 & $37.61[0.03]$ & $14.18[0.28]$ & $3.56[0.48]$ & $23.43[0.03]$ & $10.62[0.28]$ & $3.56[0.48]$ & $5.03[0.02]$ & $0.17[0.68]$ & No & No & Yes \\
\hline & ER_end & 35 & 3 & 2 & $38.73[0.02]$ & $14.17[0.28]$ & $3.94[0.42]$ & $24.56[0.02]$ & $10.24[0.31]$ & $3.94[0.42]$ & $4.05[0.04]$ & $0.74[0.39]$ & No & No & Yes \\
\hline & GCF & 34 & 4 & 4 & $52.14[0.00]$ & $14.25[0.64]$ & $5.29[0.56]$ & $37.89[0.00]$ & $8.96[0.73]$ & $5.29[0.56]$ & $0.09[0.77]$ & $7.44[0.01]$ & No & Yes & No \\
\hline & LendingR & 35 & 3 & 4 & $43.57[0.04]$ & $14.88[0.58]$ & $3.13[0.86]$ & $28.70[0.02]$ & $11.75[0.44]$ & $3.13[0.86]$ & $5.75[0.02]$ & $2.92[0.09]$ & Yes & Yes & Yes \\
\hline & Tel100 & 35 & 3 & 3 & $34.46[0.01]$ & $12.56[0.13]$ & $2.57[0.11]$ & $21.89[0.04]$ & $9.99[0.21]$ & $2.57[0.11]$ & $4.72[0.03]$ & $0.09[0.77]$ & No & No & Yes \\
\hline & UrbanPop & 34 & 4 & 4 & $46.46[0.02]$ & $18.62[0.30]$ & $7.72[0.28]$ & $27.84[0.03]$ & $10.90[0.52]$ & $7.72[0.28]$ & $10.86[0.00]$ & $0.49[0.49]$ & No & No & Yes \\
\hline
\end{tabular}

Notes: See Table 2 for definition of control variables. Parentheses [ ] are used to denote the relevant probability values. Obs - observations; $K-$ number of lags; $A-$ deterministic assumption; $Y-\mathrm{G}$

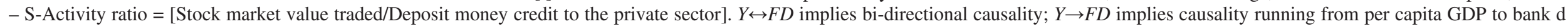
ment and $Y \leftarrow F D$ implies causality running from bank development to per capita GDP. 
Table 5. Cointegration and weak exogeneity test results for Egypt, Nigeria and South Africa: S-Size and per capita GDP

\begin{tabular}{|c|c|c|c|c|c|c|c|c|c|c|c|c|c|c|c|}
\hline & & & & & Trace statistic & & & Max Eigenvalue & & & Weak Exogeneity Test & & $\begin{array}{c}\text { Causality between } \mathrm{Y} \\
\text { and FD }\end{array}$ & & \\
\hline \multirow{12}{*}{ Egypt } & Control variable & Obs & $\mathrm{K}$ & A & $r<0$ & $r<1$ & $r<2$ & $r<0$ & $r<1$ & $r<2$ & $Y$ & $F D$ & $Y \leftrightarrow F D$ & $Y \rightarrow F D$ & $Y \leftarrow F D$ \\
\hline & ElecPecapita & 27 & 3 & 4 & $78.76[0.00]$ & $12.68[0.76]$ & $4.83[0.62]$ & $66.08[0.00]$ & $7.85[0.84]$ & $4.83[0.62]$ & $1.12[0.29]$ & $7.20[0.01]$ & No & Yes & No \\
\hline & Exports & 0 & 0 & 0 & $54.58[0.00]$ & $19.11[0.07]$ & $4.93[0.29]$ & $35.47[0.00]$ & $14.18[0.09]$ & $4.93[0.29]$ & $6.20[0.01]$ & $1.82[0.18]$ & No & No & Yes \\
\hline & GCF & 29 & 3 & 4 & $50.76[0.01]$ & $18.92[0.29]$ & $2.96[0.88]$ & $31.84[0.01]$ & $15.97[0.15]$ & $2.96[0.88]$ & $1.11[0.29]$ & $9.85[0.00]$ & No & Yes & No \\
\hline & Imports & 29 & 3 & 3 & $32.56[0.02]$ & $8.43[0.42]$ & $0.00[1.00]$ & $24.14[0.02]$ & $8.43[0.34]$ & $0.00[1.00]$ & $5.89[0.02]$ & $1.21[0.27]$ & No & No & Yes \\
\hline & Industr & 29 & 3 & 2 & $35.78[0.04]$ & $13.24[0.34]$ & $4.02[0.41]$ & $4.02[0.41]$ & $9.23[0.41]$ & $4.02[0.41]$ & $4.70[0.03]$ & $5.97[0.01]$ & Yes & Yes & Yes \\
\hline & \begin{tabular}{|l|} 
NetTaxes \\
\end{tabular} & 28 & 4 & 2 & $54.75[0.00]$ & $19.11[0.07]$ & $6.59[0.15]$ & $35.64[0.00]$ & $12.52[0.16]$ & $6.59[0.15]$ & $3.53[0.06]$ & $0.00[0.96]$ & No & No & Yes \\
\hline & OPP & 29 & 3 & 3 & $38.78[0.00]$ & $9.315[0.34]$ & $0.11[0.74]$ & $29.47[0.00]$ & $9.21[0.27]$ & $0.11[0.74]$ & $4.04[0.04]$ & $0.33[0.57]$ & No & No & Yes \\
\hline & \begin{tabular}{|l|} 
PDensity \\
\end{tabular} & 29 & 3 & 3 & $54.50[0.00]$ & $13.58[0.10]$ & $1.11[0.29]$ & $40.91[0.00]$ & $12.47[0.09]$ & $1.11[0.29]$ & $9.74[0.00]$ & $0.49[0.48]$ & No & No & Yes \\
\hline & Pop & 29 & 3 & 3 & $54.50[0.00]$ & $13.58[0.10]$ & $1.11[0.29]$ & $40.91[0.00]$ & $12.47[0.09]$ & $1.11[0.29]$ & $9.74[0.00]$ & $0.49[0.48]$ & No & No & Yes \\
\hline & \begin{tabular}{|l|} 
Tel \\
\end{tabular} & 30 & 2 & 2 & $41.49[0.01]$ & $13.72[0.31]$ & $5.13[0.27]$ & $27.77[0.01]$ & $8.60[0.48]$ & $5.13[0.27]$ & $22.33[0.00]$ & $0.86[0.35]$ & No & No & Yes \\
\hline & \begin{tabular}{|l|} 
Tel100 \\
\end{tabular} & 30 & 2 & 2 & $40.87[0.01]$ & $13.90[0.30]$ & $5.06[0.28]$ & $26.96[0.01]$ & $8.85[0.45]$ & $5.06[0.28]$ & $21.58[0.00]$ & $0.83[0.36]$ & No & No & Yes \\
\hline Nigeria & Agric & 28 & 4 & 4 & $49.46[0.01]$ & $11.82[0.82]$ & $4.52[0.67]$ & $37.64[0.00]$ & $7.31[0.88]$ & $4.52[0.67]$ & $1.48[0.22]$ & $8.70[0.00]$ & No & Yes & No \\
\hline \multirow{11}{*}{ South Africa } & $\mathrm{CPI}$ & 29 & 3 & 3 & $39.49[0.00]$ & $9.56[0.32]$ & $0.55[0.46]$ & $29.93[0.00]$ & $9.01[0.29]$ & $0.55[0.46]$ & $0.32[0.57]$ & $5.519[0.02]$ & No & Yes & No \\
\hline & \begin{tabular}{|l} 
Elec \\
\end{tabular} & 26 & 4 & 3 & $44.67[0.00]$ & $9.76[0.30]$ & $0.02[0.88]$ & $34.91[0.00]$ & $9.74[0.23]$ & $0.02[0.88]$ & $7.86[0.01]$ & $0.59[0.44]$ & No & No & Yes \\
\hline & Exports & 27 & 5 & 4 & $71.29[0.00]$ & $22.16[0.14]$ & $6.46[0.40]$ & $49.13[0.00]$ & $15.70[0.16]$ & $6.46[0.40]$ & $5.22[0.02]$ & $0.16[0.69]$ & No & No & Yes \\
\hline & Imports & 28 & 4 & 4 & $65.09[0.00]$ & $22.86[0.11]$ & $6.57[0.39]$ & $42.23[0.00]$ & $16.29[0.13]$ & $6.57[0.39]$ & $0.22[0.64]$ & $9.84[0.00]$ & No & Yes & No \\
\hline & Industr & 28 & 4 & 4 & $55.02[0.00]$ & $25.85[0.05]$ & $9.11[0.17]$ & $9.11[0.17]$ & $16.73[0.12]$ & $9.11[0.17]$ & $0.00[0.97]$ & $8.85[0.00]$ & No & Yes & No \\
\hline & \begin{tabular}{|l|} 
NetTaxes \\
\end{tabular} & 29 & 3 & 2 & $44.95[0.00]$ & $16.96[0.13]$ & $5.90[0.20]$ & $27.99[0.01]$ & $11.06[0.25]$ & $5.90[0.20]$ & $0.67[0.41]$ & $3.12[0.08]$ & No & Yes & No \\
\hline & ER_av & 35 & 3 & 4 & $47.02[0.02]$ & $19.29[0.26]$ & $6.96[0.35]$ & $27.74[0.03]$ & $12.33[0.39]$ & $6.96[0.35]$ & $4.25[0.04]$ & $9.39[0.00]$ & Yes & Yes & Yes \\
\hline & GvtCons & 36 & 2 & 4 & $33.57[0.02]$ & $11.56[0.18]$ & $0.00[0.97]$ & $22.01[0.04]$ & $11.56[0.13]$ & $0.00[0.97]$ & $0.00[0.98]$ & $6.20[0.01]$ & No & Yes & No \\
\hline & Imports & 36 & 2 & 4 & $56.05[0.00]$ & $25.44[0.06]$ & $8.61[0.21]$ & $30.61[0.01]$ & $16.83[0.11]$ & $8.61[0.21]$ & $0.13[0.72]$ & $9.61[0.00]$ & No & Yes & No \\
\hline & OPP & 36 & 2 & 4 & $57.61[0.00]$ & $24.46[0.07]$ & $6.63[0.38]$ & $33.15[0.00]$ & $17.83[0.08]$ & $6.63[0.38]$ & $0.32[0.57]$ & $6.83[0.01]$ & No & Yes & No \\
\hline & UrbanPop & 36 & 2 & 4 & $48.59[0.01]$ & $17.32[0.39]$ & $4.25[0.71]$ & $31.27[0.01]$ & $13.07[0.32]$ & $4.25[0.71]$ & $0.01[0.94]$ & $6.18[0.01]$ & No & Yes & No \\
\hline
\end{tabular}

Source: Compiled by author. 